nghiên cứu cho thấy có 78,1\% ĐD, HS thực hiện đúng kỹ thuật vệ sinh tay trước khi mang găng tay và sau khi tháo găng tay,

Tỷ lệ đối tượng nghiên cứu thực hành đúng quy trình cao hơn kết quả $48,2 \%$ điêu dưỡng thực hành tốt kiểm soát nhiếm khuẩn trong nghiên cứu của Niraula Shrestha năm 2018, tại Bir Hospital, Kathmandu, Nepal nhưng thấp hơn nhiều so với tỷ lễ̂ 91,1\% điều dưỡng thực hành tốt kiểm soát nhiễm khuẩn trong nghiên cứu của Fashafsheh, Imad và cộng sự năm 2015 tại một số bệnh viện Palestine.

\section{KẾT LUÂ̂N}

Tỷ lệ cán bộ y tế có kiến thức đúng về vệ sinh môi trường bề mặt thiết bị y tế tại các khoa lâm sàng chỉ đạt 53,4\%.Tỷ lệ cán bộ y tế thực hành đúng quy trình về vệ sinh môi trường bề mặt thiết bị y tế tại các khoa lấm sàng chỉ đạt 61,1\%.

\section{TÀI LIÊU THAM KHẢO}

1. Bộ Y tế (2013), Kế hoạch hành động quốc gia về chống kháng thuốc giai đoạn từ năm 2013 đến
2030, Hà Nôi.

2. Bộ Y tế (2015), Qựết định 4290/QĐ-BYT về việc ban hành hướng dân vê sinh môi trường bề mằt khu vực phẫu thuâat, ban hành ngày 15/10/2015.

3. Bô Y tế (2017), Quyết đinh 3916/QĐ-BYT về viêc phê duyệt các hướng dẫn kiểm soát nhiễm khuẩn trong các cơ sở khám chữa bệnh, ban hành ngày 28/8/2017.

4. Bộ Y tế (2018), Thông tư 16/2018/BYT quy định vễ Kiểm soát nhiễm khuẩn trong các cơ sở khám bệnh, chữa bệnh, ban hành ngày 20/7/2018.

5. Andrea Jennings DrPH, RN, et al (2013): A survey of environmental service workers' knowledge and opinions regarding environmental cleaning" American journal of infection control, 41, 177-9.

6. Bộ Y tế (2012), Hướng dẫn phòng ngừa chuẩn trōng các cơ sở khám chữa bênh, chữa bênh, Hà Nôii.

7. Bộ Y tế (2012), Tài liệu đào tạo liên tục Kiểm soát nhiếm khuẩn cho nhân viên y tế tuyến cở sở, HN.

8. Sui, $Y, S_{\text {, }}$ et al, (2012), "Effectiveness of bacterial disinfectants on surfaces of mechanical ventilator systems", Respir Care, 57(2), pp, 250-6.

9. Saleem, $Z_{\text {, }}$, et al, (2018), "A multicenter point prevalence survey of health care-associated infections in Pakistan: Findings and implications", Am J Infect Control,

\title{
BIẾN CHỨNG CỦA PHẪU THUÂTT CẮT MỐNG MẮT CHU BIÊN KẾT HỢP LASER TẠO HÌNH MỐNG MẮT CHU BIÊN TRONG ĐIỀU TRI GLÔCÔM GÓC ĐÓNG CƠN CẤP KHÔNG CẮT CƠN KHÔNG KÈM THEO ĐỤC THỂ THỦY TINH
}

\section{TÓM TẮT}

Mục tiêu: Đánh giá biến chứng của phẫu thuật cắt mống mắt chu biên (MMCB) kết hợp tạo hình chẩn mống mắt bằng laser Argon (LIP) trong điều trị glôcôm góc đóng cấp không kèm theo đục thể thủy tinh không đáp ứng với điêuu trị nội khoa. Đối tượng và phương pháp: 39 mắt thỏa mãn điều kiện được đưa vào nghiên cứu từ Bệnh viện Mắt Trung ương, Bệnh viện Mắt Hà Đông và Khoa Mắt, Bệnh viện Quân y 103 trong thời gian từ 01/2018 đến 11/2019. Nghiên cứu can thiệp theo dõi dọc theo thời gian, tất cả các bệnh nhân được điều trị bằng phẫu thuật cắt $\mathrm{MMCB}+$ ALPI, thời gian theo dôi ít nhất 1 năm. Kết quả: 39 mắt đều đạt kết quả khá tốt với tỷ lệ kiểm soát nhãn áp $100 \%$ sau 1 năm theo dõi. Tuy nhiên, còn môt tỷ lệ nhất định tai biến, và biến chứng xảy ra. Tỷ lệ tai

\footnotetext{
${ }^{1}$ Bênh viện Mắt Trung ương

Bềnh viện Quân y 103, Học viện Quân y

Chịu trách nhiệm chính: Nguyến Văn Cường

Email: cuongbm4@vmmu.edu.vn

Ngày nhận bài: 4.5.2021

Ngày phản biên khoa hoc: 24.6.2021

Ngày duyệt bài: 5.7.2021
}

Đỗ Tấn ${ }^{1}$, Nguyễn Văn Cường ${ }^{2}$

biến 43,58 \% gồm xuất huyết tiền phòng (XHTP) $25,81 \%$, bỏng giác mạc 17,94\% các tai biến đều được xử lý ổn định ngay trong mổ, hoặc điêuu trị bằng nội khoa sau thủ thuật laser. Biến chứng sớm ( $<2$ tuần) là $41,03 \%$ bao gồm kẹt mống mắt mép mổ $5,13 \%$, tiên phòng nông $7,69 \%$, tăng nhãn áp 7,69\%, viêm màng bồ đào trước 20,51\%. Biến chứng muộn ( $>2$ tuần) chỉ còn $2,56 \%$. Nhãn áp tăng cao trên $35 \mathrm{mmHg}$ trước mổ có tỷ lệ XHTP sau mổ cao hơn $(<0,001$, test Chi square), viểm MBĐ cao hơn $(0,04$, test Chi square) so với nhóm nhãn áp thấp dưới $35 \mathrm{mmHg}$ trước mổ. Thời gian bi bệnh (thời gian nhãn áp cao không điều chỉnh) kéo dài trên 3 ngày cũng làm tăng nguy cơ viêm $M B Đ$ $(0,02$, test Chi square), so với nhóm kéo dài dưới 3 ngày. Độ sâu tiền phòng thấp dưới $1,5 \mathrm{~mm}$ làm tăng tỷ lệ bỏng giác mạc chu biên khi tiến hành laser tạo hình mống mắt chu biên $(0,02$, test Chi square) so với nhóm có đô sâu tiền phòng từ trên $1,5 \mathrm{~mm}$. Các tai biến, biến chứng hầu hết được kiểm soát tốt bằng cáćc điều trị bổ sung, không ảnh hưởng đến kết quả phẫu thuật sau 12 tháng. Kết luận: Phâuu thuật mống mắt chu biên phối hợp laser tạo hình mống mắt chu biên khá an toàn, mặc dù có một tỷ lệ tai biến, biến chứng nhất định nhưng ở mức độ nhẹ, có thể can thiệp dể dàng không ảnh hưởng đến kết quả cuối cùng. 
Tư khóa: Glôcôm góc đóng cấp, phẫu thuật mống mắt chu biên, tai biến, biến chứng

Lời cảm ơn: Chúng tôi xin chân thành cảm ơn nhóm nghiên cứu tại khoa Glôcôm, Bệnh Viện Mắt Trung Ương, Khoa Mắt, Quân Y 103 và Bệnh Viện Mắt Hà Đông đã tham gia vào việc điều trị và theo dõi bệnh nhân trong nghiên cứu.

\section{SUMMARY}

\section{COMPLICATIONS OF SURGICAL IRIDECTOMY AND LASER PERIPHERAL IRIDOPLASTY IN TREATMENT OF UNRESPONSIVE ACUTE PACG WITHOUT CATARACT}

Objectives: To evaluate the complications of surgical iridectomy and argon laser peripheral iridoplasty for unresponsive acute PACG with cataract. Patients and Methods: 39 eligible eyes were recruited into the study from 3 centers Vietnam National Eye Hospital, Ha Dong Eye Hospital and Eye department of 103 Military Hospital from 1/2018 to 11/2019. Results: All of 39 eyes achieved good results with $100 \%$ IOP control after 1 year of followup. However, there was a number of complications that did occur. During operation, the rate of complications was 43,58\%, including hyphema $25.81 \%$, corneal burn $17,94 \%$, all of which were managed successfully in surgery and by medical treatment after surgery. Post operation, early complications ( $<2$ weeks) $41.03 \%$ including: iris incarceration $5.13 \%$, shallow anterior chamber $7.69 \%$, elevated IOP $7.69 \%$, anterior uveitis $20.51 \%$. Late complications ( $>2$ weeks) were cataract accounting for $2.56 \%$. preoperative IOP higher than $35 \mathrm{mmHg}$ led to a higher rate of post-operative hyphema $(<0.001$, Chi square test), anterior uveitis (0.04, Chi square test) compared with the preoperative IOP below $35 \mathrm{mmHg}$. Duration of progression $>3$ days was also associated with an increased risk of anterior uveitis $(0.02$, Chi square test), compared with the group with lasting less than 3 days. Shallow anterior chamber depth less than $1.5 \mathrm{~mm}$ has higher rate of peripheral corneal burns when performing LIP (0.02, Chi square test) compared with the group with ACD of more than $1.5 \mathrm{~mm}$. Complications were mostly well controlled with additional treatments and did not affect surgical results after 12 months. Conclusion: Peripheral iridectomy combined with LIP is quite safe, although there was a certain rate of complications, but it were usually mild and can be easily managed without influence on final results.

Key words; ACAG, surgical iridectomy, laser peripheral iridoplasty, complications

\section{I. ĐĂT VẤN ĐỀ}

Glôcôm góc đóng nguyên phát cấp tính được coi là một cấp cứu nội khoa trong các bệnh lý Nhãn khoa, là dạng phá hủy thị lực nhiều nhất của nhóm bệnh glôcôm. Vì là một tình trạng cấp cứu, việc điều trị hạ nhãn áp sớm có ý nghĩa hết sức quan trọng để bảo tồn thị lực cũng như hạn chế các biến chứng có thể xảy ra do nhãn áp cao
[1]. Tuy nhiên, khi đã hạn chế được tình trạng cấp tính, thì việc điều trị glocom tiếp theo là làm sao duy trì được nhãn áp đích ổn định và hạn chế các biến chứng do thuốc và phẫu thuật [2]

Tại Việt Nam hiên nay, phẩu thuật cắt bè củng giác mạc là phẫu thuật được sử dụng rộng rãi, các nghiên cứu cũng đã cho thấy được hiệu quả rõ rệt của phẫu thuật này trên nhóm bệnh glôcôm góc đóng cơn cấp nguyên phát, song còn nhiều hạn chế dễ gặp phải tai biến, biến chứng hơn đặc biệt là các biến chứng về sẹo bọng, lổ rò [3]. Việc han chế các phẫu thuật xâm lấn là bước phát triển trong thời gian hiện nay, một số nghiên cứu trong nước và thế giới đã chứng minh được phẫu thuật cắt mống mắt chu biên phối hợp với laser argon tạo hình vùng bè có hiệu quả về mở rộng góc tiền phòng, cũng như duy trì nhãn áp ổn định lâu dài. Về cơ chế, cắt mống mắt chu biên tạo lưu thông thủy dịch giữa tiền phòng và hậu phòng, từ đó giải quyết được cơ chế tăng nhãn áp cấp do cả nghẽn đồng tử và không do nghẽn đồng tử. Việc phối hợp với laser tạo hình giúp việc mở rộng góc tiền phòng, làm đứt gãy các cầu dính ở góc tiền phòng tạo ra do quá trình nên cơn cấp kèm theo viêm VBĐ trước, làm tăng chức năng thoát lưu thủy dịch duy trì hiệu quả hạ nhãn áp lâu dài [4], [5], [6], [7]. Một số nghiên cứu trong nước đã tập trung vào đánh giá nhãn áp, thị lực, về tỷ lệ các biến chứng, tuy nhiên chưa có nghiên cứu nào mô tả nguyên nhân, cách xử trí và ảnh hưởng của tai biến, biến chứng đến kết quả phẫu thuật phối hợp này. Do vậy, chúng tôi thực hiên nghiên cứu này để đánh giá các tai biến, biến chứng của phẫu thuật cắt bè và một số yếu tố liên quan.

\section{II. ĐỐI TƯƠNGG VÀ PHƯƠNG PHÁP NGHIÊN CỨU}

Các bệnh nhân được chẩn đoán xác định là glôcôm góc đóng nguyên phát cấp tính cắt cơn không thành công không kèm đục thể thủy tinh được thu nhận tại bệnh viện Mắt Trung ương, bệnh viện Mắt Hà Đông và khoa Mắt, bệnh viện Quân y 103 trong thời gian từ 01/2018 đến $11 / 2019$.

\section{Tiêu chuẩn lựa chon:}

- Bệnh nhân được chẩn đoán là glôcôm góc đóng nguyên phát cấp tính, không đáp ứng với điêu trị nội khoa là khi nhãn áp không điêuu chỉnh và/hoặc góc tiền phòng vẫn đóng > 180 độ sau 3 ngày điêu trị nội khoa tích cực [2].

- Bệnh nhân được chẩn đoán đục thủy tinh thể từ độ I trở xuống theo phân loại LOCS III

- Không dị ứng với các thuốc điều trị nội khoa hạ nhãn áp. 
- Bệnh nhân đồng ý tham gia nghiên cứu và ký cam kết

Tiêu chuẩn loại trừ

- Bệnh nhân có viêm nhiễm cấp tính tại mắt hoăc mắc bệnh toàn thân không đảm bảo cho phẫu thuật

- Bệnh nhân không đồng ý tham gia nghiên cứu, hoặc không đồng ý chấp nhận sự ngẫu nhiên trong nghiên cứu, hoặc không thể khám lại theo hẹn.

Phương pháp nghiên cứu:

Thiết kế nghiên cứu: Nghiên cứu can thiệp theo dõi dọc theo thời gian.

Phương pháp tiến hành: Các bệnh nhân được ghi chép thông tin, đặc điểm lâm sàng trước phẫu thuât vào bênh án

Qui trình phẫu thuật cắt mống mắt chu biên: Rạch giác mạc rìa một đường dài khoảng $1,5 \mathrm{~mm}$, vuông góc. Kẹp kéo mống mắt chu biên ra ngoài, nâng nhe và cắt mống mắt bằng kéo sao cho mống mắt được cắt hoàn toàn theo chiều dày. Đẩy mống mắt vào tiền phòng, bơm nước tái tạo tiền phòng. Bơm phù mép mổ.

Quy trình laser tạo hình chân mống mắt: Được tiến hành sau hoặc trước phẫu thuật cắt MMCB trong vòng 7 ngày. Sử dụng laser argon, các thông số kỹ thuật ban đầu thường là $200 \mu \mathrm{m}$, 200 ms, $400 \mathrm{~mW}$. Điều chỉnh năng lượng theo đáp ứng tại chỗ: tăng năng lượng khi không có sự co rút nhu mô, ngược lại giảm năng lượng khi có vết đốt gây giải phóng nhiêu sắc tố, hoặc tạo bot khí. Số lương vết đốt ở mỗi góc phần tư từ 6 10 vết đốt mối góc làm cả 360 độ ở 1 lần điêu trị.

\section{Các chỉ tiêu nghiên cứu}

+ Đặc điểm chung bệnh nhân

+ Hiệu quả điều chỉnh nhãn áp, cải thiện thị lực ở tháng 12

+ Các tai biến, biến chứng (sớm và muộn)

+ Mối liên quan giữa tai biến, biến chứng với hiệu quả điều trị

Phân tích số liệu: sử dụng các thuật toán thống kê theo phần mềm SPSS 16.

Đạo đức nghiên cứu: Nghiên cứu được Hội đồng đạo đức trong nghiên cứu $Y$ sinh học của cả 3 Bệnh viện thông qua

\section{KẾT QUẢ NGHIÊN CỨU}

Các đăcc điểm chung. Nghiên cứu được tiến hành nghiên cứu trên 39 mắt của 39 bệnh nhân glocom góc đóng cơn cấp không kèm theo đục thể thủy tinh thất bại sau điều trị nội khõa tối đa có chỉ định điều trị phẫu thuật bằng phẫu thuật cắt MMCB kết hợp LPI.

Bảng 1. Đặc điểm chung của bệnh nhân

\begin{tabular}{|c|c|c|c|}
\hline Đặc điếm & \multicolumn{2}{|c|}{ Phân nhóm } & Kết quả \\
\hline \multirow{4}{*}{ Tuổi } & \multicolumn{2}{|c|}{ Trung bình (tuổi) } & $\begin{array}{c}57,79 \pm 7,68 \\
(36-75)\end{array}$ \\
\hline & \multicolumn{2}{|c|}{ Dưới 40 tuối } & $7(17,94 \%)$ \\
\hline & \multicolumn{2}{|c|}{ Từ 40 - 60 tuối } & $24(61,53 \%)$ \\
\hline & \multicolumn{2}{|c|}{ Trên 60 tuối } & $8(20,5 \%)$ \\
\hline \multirow{3}{*}{ Giới } & \multicolumn{2}{|c|}{ Nam } & $12(30,76 \%)$ \\
\hline & \multicolumn{2}{|c|}{ Nũ̃ } & $27(69,23 \%)$ \\
\hline & \multicolumn{2}{|c|}{ Tỷ lệ nữ/nam } & $2,25 / 1$ \\
\hline \multirow{5}{*}{ Thị lực } & \multicolumn{2}{|c|}{$\begin{array}{l}\text { Trung bình } \\
\text { (LogMAR) }\end{array}$} & $\begin{array}{c}1,16 \pm 0,72 \\
(2-0,3)\end{array}$ \\
\hline & \multicolumn{2}{|c|}{$<$ ĐNT $3 \mathrm{~m}$} & $4(10,25 \%)$ \\
\hline & \multicolumn{2}{|c|}{ ĐNT $3 \mathrm{~m}-20 / 80$} & $28(71,79 \%)$ \\
\hline & \multirow{2}{*}{\multicolumn{2}{|c|}{$\begin{array}{c}20 / 80-20 / 30 \\
>20 / 30\end{array}$}} & $7(17,94 \%)$ \\
\hline & & & 0 \\
\hline \multirow{3}{*}{$\begin{array}{l}\text { Nhãn áp } \\
\text { trước } \\
\text { phẫu } \\
\text { thuật }\end{array}$} & \multicolumn{2}{|c|}{ Trung bình } & $32,11 \pm 7,32$ \\
\hline & \multicolumn{2}{|c|}{ Trên 35 mmHg } & $22(56,41 \%)$ \\
\hline & \multicolumn{2}{|c|}{ Dưới 35 mmHg } & $17(43,89 \%)$ \\
\hline \multirow{3}{*}{$\begin{array}{l}\text { Thời } \\
\text { gian bị } \\
\text { bệnh }\end{array}$} & \multicolumn{2}{|c|}{ Trung bình (ngày) } & $\begin{array}{c}2,89 \pm 1,04 \\
(1-5)\end{array}$ \\
\hline & \multicolumn{2}{|c|}{ Trên 3 ngày } & $16(41,03 \%)$ \\
\hline & \multicolumn{2}{|c|}{ Từ 1- 3 ngày } & $23(58,97 \%)$ \\
\hline \multirow{3}{*}{$\begin{array}{l}\text { Độ sâu } \\
\text { tiền } \\
\text { phòng }\end{array}$} & \multicolumn{2}{|c|}{ Trung bình (mm) } & $\begin{array}{c}2,02 \pm 0,45 \\
(1,09-2,33)\end{array}$ \\
\hline & \multicolumn{2}{|c|}{ Dưới 1,5mm } & $19(48,71 \%)$ \\
\hline & \multicolumn{2}{|c|}{ Trên $1,5 \mathrm{~mm}$} & $20(51,28 \%)$ \\
\hline \multirow{7}{*}{$\begin{array}{l}\text { Đố mở } \\
\text { góc tiền } \\
\text { phòng } \\
\text { (góc } \\
\text { phần tư) }\end{array}$} & \multicolumn{2}{|c|}{$\begin{array}{c}\text { Trung bình (độ } \\
\text { Shaffer) }\end{array}$} & $\begin{array}{c}0,67 \pm 0,46 \\
(0-2)\end{array}$ \\
\hline & \multirow{2}{*}{$\begin{array}{l}\text { Góc } \\
\text { độ } 0\end{array}$} & Dính góc & $26(16,88 \%)$ \\
\hline & & Không dính & $44(28,57 \%)$ \\
\hline & \multirow{2}{*}{$\begin{array}{l}\text { Góc } \\
\text { độ } 1 \\
\end{array}$} & Dính góc & $18(46,15 \%)$ \\
\hline & & Không dính & $42(27,27 \%)$ \\
\hline & \multirow{2}{*}{$\begin{array}{l}\text { Góc } \\
\text { độ } 2\end{array}$} & Dính góc & $8(5,19 \%)$ \\
\hline & & Không dính & $16(10,38 \%)$ \\
\hline
\end{tabular}

Theo bảng 1, bệnh nhân được chỉ định phầu thuật cắt bè trong nghiên cứu này chủ yếu ở nhóm tuổi trên 40, ở nữ giới, độ sâu tiền phòng thấp, thị lực thấp (chủ yếu dưới 20/80).

Các tai biến và biến chứng. Tất cả 39 mắt của nghiên cứu đều có kết quả chức năng và nhãn áp tương đối tốt. Toàn bộ mắt trong nghiên cứu có mức nhãn điều chỉnh không thuốc sau 1 năm theo dõi. Theo dõi tai biến, biến chứng thấy rằng có 25 mắt xảy ra tai biến và hoặc biến chứng (17 mắt có tai biến, 16 mắt có biển chứng)

Các phẩu thuật trong nghiên cứu đều được thực hiện bởi các phẩu thuật viên có kính nghiệm. Chúng tôi không gặp các tai biến nặng như: xuất huyết tống khứ, chạm thể thủy tinh, rách bờ đồng tử, rách chân mống mắt nhưng còn gặp phải tỷ lệ nhất định như xuất huyết tiền phòng (XHTP) và bỏng giác mạc chu biên. 
Bảng 2. Phân bố các tai biến trong mổ

\begin{tabular}{|c|c|c|c|}
\hline Tai biến & Tỷ lệ & Xử trí & $\begin{array}{l}\text { Thời gian } \\
\text { tiến triển }\end{array}$ \\
\hline $\begin{array}{c}\text { Xuất } \\
\text { huyết tiền } \\
\text { phòng }\end{array}$ & $\begin{array}{c}10 \\
(25,64 \%)\end{array}$ & $\begin{array}{c}\text { Rưa tiền } \\
\text { phòng - } \\
\text { dung } \\
\text { Adrenaline } \\
\text { pha loãng } \\
\text { bơm vào tiên } \\
\text { phòng }\end{array}$ & $\begin{array}{l}0,95 \pm 1,29 \\
(0-4 \text { ngày) }\end{array}$ \\
\hline $\begin{array}{c}\text { Bỏng giác } \\
\text { mac chu } \\
\text { biên }\end{array}$ & $\begin{array}{c}7 \\
(17,94 \%)\end{array}$ & $\begin{array}{c}\text { Chống viêm } \\
\text { corticoid tại } \\
\text { chố }\end{array}$ & $\begin{array}{c}6,23 \pm 2,68 \\
(5-10 \text { ngày) }\end{array}$ \\
\hline
\end{tabular}

Theo bảng 2, XHTP xảy ra trên $10 \mathrm{ca}$ $(25,64 \%)$ nguyên nhân xuất huyết đều do bước cắt mống mắt chu biên, không trường hợp nào liên quan tới laser tao hình. Mức đô XHTP từ đô 1 đến độ 2 , trong đó $7 \mathrm{ca}(70 \%)$ mức độ 1,3
(30\%) ca mức độ 2 . Theo hiệu quả xử trí $8 / 10$ ca $(80 \%)$ được xử lý hoàn toàn ngay trong phẫu thuật với rửa tiền phòng với dung dịch Adrenalin $0,5 \%, 2 / 10 \mathrm{ca}(20 \%)$ sau khi rửa tiền phòng vẫn còn dải xuất huyết.

Bỏng giác mạc chu biên do laser xảy ra trên 7 ca $(17,94 \%)$, nguyên nhân là do tia laser vó điểm nổ sát với mặt sau giác mạc. Tất cả các trường hợp đều ở mức độ nhẹ, bị bỏng tại 1 vị trí laser, điêu trị nội khoa ổn định trong vòng 10 ngày sau laser.

Sau phẫu thuâtt và theo dõi, các biến chứng năng như: hạ nhãn áp $(<6 \mathrm{mmHg})$, xuất huyết tiền phòng ( 2 ca do tai biến), bong hắc mạc, bong dịch kính sau, thủy dịch ngược dòng, bong màng Descemet, viêm mủ nội nhãn, đục thủy tinh thể không xuất hiện trong nghiên cứu của chúng tôi. Các biến chứng phân bố theo bảng 3 sau đây:

Bảng 3. Phân bố các biến chứng sau mổ

\begin{tabular}{|c|c|c|c|c|}
\hline \multirow[b]{2}{*}{ Biến chứng } & \multicolumn{2}{|c|}{$\begin{array}{c}\text { Tỷ lệ } \\
\end{array}$} & \multirow[b]{2}{*}{ Điêu trị } & \multirow{2}{*}{$\begin{array}{l}\text { Thời gian } \\
\text { tiến triển }\end{array}$} \\
\hline & $\begin{array}{c}\text { Sớm (<2tuân) } \\
n=16\end{array}$ & $\begin{array}{c}\text { Muộn ( } \\
n=1\end{array}$ & & \\
\hline $\begin{array}{l}\text { Kẹt mống mắt } \\
\text { mép mổ }\end{array}$ & $2(5,13 \%)$ & 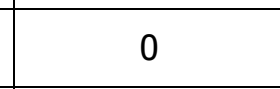 & \multirow{2}{*}{$\begin{array}{c}\text { Phâu thuật đấy lại MM vào tiền } \\
\text { phòng, bơm phù lại mép mổ } \\
\text { Mép mố chưa kín, bơm phù lại } \\
\text { mép mố }\end{array}$} & 1 ngày \\
\hline Tiền phòng nông & $3(7,69 \%)$ & 0 & & 1 ngày \\
\hline Tăng nhãn áp & $3(7,69 \%)$ & 0 & \multirow{4}{*}{$\begin{array}{c}\text { nhẫ áp bằng thuốc tra } \\
\text { Xuất hiện sau laser tåo hình } \\
\text { MM, chống viêm tại chố, toàn } \\
\text { thân }\end{array}$} & $\begin{array}{l}2,04 \pm 1,23 \\
\text { (2-4 ngày) }\end{array}$ \\
\hline Viêm màng bồ đào & Tyndal (+) & 1 & & \multirow{3}{*}{$\begin{array}{l}5,34 \pm 2,16 \\
\text { (3-7 ngày) }\end{array}$} \\
\hline trước $(\mathrm{n}=8$, & Tyndal $(++)$ & 0 & & \\
\hline $20,51 \%)$ & \begin{tabular}{|l|l} 
Tyndal $(+++)$ & 1 \\
\end{tabular} & 0 & & \\
\hline Tống & $41,03 \%$ & $2,56 \%$ & & \\
\hline
\end{tabular}

Theo bảng 3, các biến chứng đã giảm nhanh thông qua các điều trị bổ sung, tỷ lệ biến chứng tại thời điểm trước 2 tuần và sau 2 tuần (41,03\% so với $2,56 \%)$, khác biệt có ý nghĩa thống kê $p<0,001$ (test Fischer exact).

Theo phương pháp điều trị có $5 / 16$ ca $(31,25 \%)$ đã được điều trị bổ sung bằng phẫu thuật, 11/16 (68,75\%) được điều trị bằng nội khoa, sự khác biệt có ý nghĩa thống kê $p<0,001$ (test Fischer exact).

Các biến chứng tiền phòng nông do hở mép mổ, ket mống mắt mép mổ, tăng nhãn áp sau laser tạo hình đều được phát hiện sớm và xử lý

ngay. Viêm màng bồ đào (VMBĐ) trước được phát hiện với tỷ lệ cao nhất $8 / 39$ ca $(20,51 \%)$ chiếm 49,98\% tổng số biến chứng sớm. Các ca VMBĐ chủ yếu ở mức độ nhe Tyndall $(+)$ chiếm $75 \%$, không ca nào có xuất tiết diện đồng tử. Điều trị nội khoa với chống viêm tại chỗ cải thiện hoàn toàn sau $5,34 \pm 2,16$ (3-7 ngày)

Đánh giá các tai biến, biến chứng theo các đặc điểm trước phẫu thuật (bảng 1), thấy có có một số yêu tố có ảnh hưởng có ý nghĩa thống kê tới nguy cơ xảy ra tai biến, biến chứng như bảng 4 sau:

Bảng 4. Môi liên quan tai biến, biến chứng và một số đặc điểm trước phẫu thuật

\begin{tabular}{|c|c|c|c|c|}
\hline \\
\hline Đặc điểm & Phân nhóm & XHTP $(n=10)$ & $\begin{array}{l}\text { Bỏng giác mạc } \\
\text { chu biên }(n=7)\end{array}$ & $\begin{array}{c}\text { Viêm MBĐ } \\
(n=8)\end{array}$ \\
\hline \multirow{2}{*}{ Nhãn áp } & Trên 35 mmHg $(n=22)$ & $7(31,81 \%)$ & $4(18,18 \%)$ & $6(23,07 \%)$ \\
\hline & Dưới $35 \mathrm{mmHg}(\mathrm{n}=17)$ & $3(17,64 \%)$ & $3(17,64 \%)$ & $2(11,76 \%)$ \\
\hline \multirow{3}{*}{$\begin{array}{l}\text { Thời gian } \\
\text { bị bệnh }\end{array}$} & $\mathrm{p}$ & $<0,001$ & 0,12 & 0,04 \\
\hline & Trền 3 ngày $(n=16)$ & $4(25 \%)$ & $3(18,75 \%)$ & $5(31,25 \%)$ \\
\hline & Từ 1-3 ngày $(n=23)$ & $6(26,09 \%)$ & $4(17,39 \%)$ & $3(13,04 \%)$ \\
\hline
\end{tabular}




\begin{tabular}{|c|c|c|c|c|}
\hline \multicolumn{2}{|c|}{$p$} & 0,09 & 0,07 & 0,02 \\
\hline Độ sâu & Dưới 1,5mm $(n=19)$ & $4(21,57 \%)$ & $5(26,31 \%)$ & $5(26,31 \%)$ \\
\cline { 2 - 5 } tiền phòng & Trên 1,5mm $(n=20)$ & $5(25 \%)$ & $2(10 \%)$ & $4(20 \%)$ \\
\hline$p$ & & 0,11 & 0,02 & 0,08 \\
\hline
\end{tabular}

Theo bảng 4 , nhãn áp tăng cao trên 35 $\mathrm{mmHg}$ đã nguy cơ xảy ra XHTP $(<0,001$, test Chi square), viêm $\operatorname{MBĐ}(0,04$, test Chi square) so với nhóm nhãn áp thấp dưới $35 \mathrm{mmHg}$.

Thời gian bị bệnh (thời gian nhãn áp cao không điều chỉnh) kéo dài trên 3 ngày cũng làm

\section{Ảnh hưởng của tai biến, biến chứng đến kết quả phẫu thuật sau 12 tháng}

Bảng 5. Mối liên quan kết quả phẫu thuật và biến chứng

\begin{tabular}{|c|c|c|c|c|}
\hline \multicolumn{2}{|c|}{ Kết quả phẫu thuật } & $\begin{array}{c}\text { Có biến chứng } \\
(\mathbf{n = 2 5 )}\end{array}$ & $\begin{array}{c}\text { Không biến chứng } \\
(\mathbf{n = 1 4 )}\end{array}$ & $\mathbf{p}$ \\
\hline \multirow{3}{*}{$\begin{array}{c}\text { Nhãn } \\
\text { áp }\end{array}$} & Nhãn áp chung $(\mathrm{mmHg})$ & $17,27 \pm 5,46$ & $16,89 \pm 6,23$ & 0,12 \\
\cline { 2 - 5 } & Từ $18-21 \mathrm{mmHg}(\mathrm{n}=5)$ & $3(12 \%)$ & $2(14,28 \%)$ & 0,21 \\
\cline { 2 - 5 } & Từ 15 -18 mmHg $(\mathrm{n}=21)$ & $14(56 \%)$ & $8(57,14 \%)$ & 0,17 \\
\cline { 2 - 5 } & Dưới $15 \mathrm{mmHg}(\mathrm{n}=13)$ & $8(32 \%)$ & $4(28,57 \%)$ & 0,24 \\
\hline \multirow{2}{*}{ Thị lực } & Thị lực trung bình (LogMAR) & $0,45 \pm 0,39(0,25-0,8)$ & $0,47 \pm 0,62(0,2-0,63)$ & 0,15 \\
\cline { 2 - 5 } & Nhóm <20/200 (n=0) & 0 & 0 & \\
\hline
\end{tabular}

Theo bảng 6 , kết quả về nhãn áp và thị lực sau 12 tháng phẫu thuật đều cải thiện và duy trì ổn định, không có sự khác biệt có ý nghĩa thống kê giữa nhóm có biến chứng và nhóm không có biến chứng.

\section{BÀN LUẬN}

Trên 39 mắt nghiên cứu của 39 bệnh nhân $(\mathrm{BN})$, được tiến hành phẫu thuật cắt $\mathrm{MMCB}+$, LIP bổ sung các điều trị cần thiết khi gặp phải tai biến, biến chứng. Sau 12 tháng theo dõi, tỷ lệ kiểm soát nhãn áp $100 \%$. Theo dõi tai biến, biến chứng thấy rằng có 25 mắt xảy ra tai biến và hoặc biến chứng (17 mắt có tai biến, 16 mắt có biến chứng).

Về tai biến xảy ra trong phẫu thuật, các phẫu thuật trong nghiên cứu đều được thực hiện bởi các phẫu thuật viên có kính nghiệm, đo đó các biến chứng nă̆ng như chạm thể thủy tinh thoát dịch kính, xuất huyết tống khứ không xảy ra. Tuy nhiên tỷ lệ tai biến xảy ra còn cao $(43,58 \%)$ gồm: xuất huyết tiền phòng (XHTP) $25,64 \%$ và bỏng giác mạc chu biên 17,94\% đều ở mức độ nhe và được xử trí ổn định ngay trong phẫu thuật hoặc điều trị nội khoa sau mổ bảng 2

XHTP là môt biến chứng được nhắc đến nhiều trong phẫu thuật nội nhãn nói chung và đặc biệt trên nhóm glôcôm góc đóng cơn cấp chưa cắt cơn trên nội khoa (nhãn áp còn cao, giác mạc còn phù, góc chưa mở hoàn toàn) [2]. Với nguyên nhân chủ yếu là do chạm vào vòng động mạch chân mống mắt khi cắt mống mắt sát rìa [3]. Đánh giá các yếu tố liên quan trước phẫu thuật cho thấy ảnh hưởng của nhãn áp cao trước phấu thuật làm tăng tỷ lệ XHTP bảng 4 , điều này được giải thích bởi nhã̉n áp tăng cao sẽ ảnh hưởng trực tiếp tới áp lực trong lòng mạch, khi phẫu thuật có thể chạm vào các mạch máu đang cương tụ của mống mắt cũng gây ra tình trạng xuất huyết rõ ràng hơn. Để xử trí với XHTP, ngay trong phấu thuật cần dừng lại, bơm dung dịch Adrenaline pha loãng $(0,5 \%)$ bơm vào tiền phòng gây co mạch, bơm khí tiền phòng để ép mạch máu câm máu. Các nghiên cứu về xử trí XHTP trong mổ, cũng đã sử dụng các hoạt chất gây co mạch để xử trí biến chứng XHTP và cho thấy hiệu quả rõ rệt cũng như tính an toàn với nội mô giác mạc và các kết quả phẫu thuật [7]. Với nghiên cứu này, chỉ có $2 / 10$ trường hợp do xuất huyết nhanh nên tao ra dải máu đông không được rửa hết trong phấu thuật mà tiêu dần theo thời gian. Các bệnh nhân có tai biến XHTP đều được bổ sung thuốc cầm máu (transamin), corticoid đường tĩnh mạch để hạn chế xuất huyết tái phát. Như vậy, để hạn chế biến chứng XHTP cần ha nhãn áp tốt trước phẫu thuật kèm theo các biện pháp chống viêm làm giảm cương tụ mạch máu trên mống mắt, và bổ sung điều trị nội khoa và theo dõi kỹ sau phẫu thuật.

Bỏng giác mạc chu biên xuất hiện trong bước laser tạo hình mống mắt chu biên, đây là tai biến khá thường gặp trong các thủ thuật có liên quan đến laser Argon [5], [6]. Trong nghiên cứu này, tỷ lệ bỏng giác mạc chu biên là 17,94\%, cao hơn so với các nghiên cứu về thủ thuật laser nói chung [5]. Điêuu này có thể giải thích nguyên 
nhân do: laser được tiến hành trên mắt glôcôm cấp, giác mạc tổn thương mờ đục do tác động của tăng nhãn áp do vậy ảnh hưởng tới khả năng quan sát vị trí laser cũng như chọn điểm hội tụ của chùm laser, tiên phòng nông hơn rất nhiều trên các mắt này dân tới nguy cơ tổn thương tăng rõ rệt. Đánh giá mối liên quan giữa bỏng giác mạc chu biên và độ sâu tiền phòng cho thấy, độ sâu tiền phòng thấp dưới $1,5 \mathrm{~mm}$ làm tăng tỷ lệ bỏng giác mạc chu biên khi tiến hành laser tạo hình mống mắt chu biên $(0,02$, test Chi square) so với nhóm có độ sâu tiền phòng từ trên $1,5 \mathrm{~mm}$. Tuy nhiên, bỏng giác mạc chu biên trong nghiên cứu của chúng tôi hầu hết chỉ xuất hiện ở 1 góc phần tư, điều này liên quan tới đô vồng mống mắt tai vị trí đó, dẫn tới khoảng cách mống mắt, mặt sau giác mạc càng gần hơn và gây bỏng. Như vậy, để hạn chế của biến chứng này, thứ nhất cần điều trị nôi khoa tốt làm trong giác mạc tối đa trước khi tiến hành thủ thuật laser, thứ hai cần lựa chọn các vị trí laser phù hợp, có thể bổ sung laser tạo hình thành nhiều đợt.

Trong 2 tuần sau phẫu thuâtt tỷ lệ biến chứng cao $41,03 \%$ bao gồm kẹt mống mắt mép mổ $5,13 \%$, tiền phòng nông $7,69 \%$, tăng nhãn áp $7,69 \%$, viêm màng bồ đào trước $20,51 \%$, tỷ lệ này giảm nhanh sau khi được can thiệp bố sung. Kết quả là sau 2 tuần, tỷ lệ biến chứng giảm rõ rệt còn $2,56 \%$.

Kẹt mống mắt là một biến chứng thường gặp trong phẫu thuật cắt mống mắt chu biên, mống mắt kẹt tại đường mổ giác mạc mạc rìa làm đồng tử bị biến dạng, nếu không được xử trí kịp thời sẽ gầy ra nhiều biến chứng viềm dính tại chỗ, hạn chế hiệu quả điều chỉnh nhãn áp. Trên nghiên cứu của chúng tôi, có 2 trường hợp phát hiện kẹt mống mắt ở ngày thứ 1 sau mổ. Nguyên nhân được đánh giá sơ bộ là do mép mổ rộng, mống mắt nhẽo nên mống mắt dễ chui vào mép mổ hơn. Tất cả các trường hợp này được tiến hành phẫu thuật đẩy lại mống mắt, làm sâu tiền phòng, bơm phù mép mổ kín lại, không trường hợp nào phải khâu lại mép mổ. Với biến chứng này, đánh giá tương quan với kết quả phẫu thuật đều không cho thấy sự ảnh hưởng lên nhãn áp và thị lực sau cùng. Như vậy, dù biến chứng không gây ảnh hưởng, nhưng cần theo dõi phát hiện sớm để xử lý.

Tiền phòng nông cũng là một biến chứng liên quan tới đường mổ, liên quan tới mép mổ chưa kín, rò thủy dịch. Trong nghiên cứu này, tỷ lệ tiền phòng nôngchiếm $7,69 \%$, các trường hợp này đều được phát hiện ngay ngày thứ 1 , và đều được giải quyết bằng phẫu thuật đơn giản là làm sâu lại tiền phòng và bơm phù làm kín mép mổ. Tiền phòng nông mặc dù có liên quan nhiều tới bong hắc mac sau phẫu thuâtt cắt mống mắt chu biên trên bệnh nhân glô côm góc đóng cơn cấp, tuy nhiên, các trường hợp của chúng tôi đều được siêu âm và không phát hiện bong hắc mạc. Sau điều trị bổ sung, tình trạng xẹp tiền phòng đều được giải quyết tốt, kết quả về nhãn áp và thị lực cuối cùng đều không bị ảnh hưởng.

Tăng nhãn áp là một biến chứng xuất hiện sau laser tao hình mống mắt chu biên, chiếm tỷ lệ 7,69\%, khác với laser cắt mống mắt chu biên, số lượng nhát bắn với laser tạo hình nhiều hơn, ở ở gần như toàn bô chu vi của chấn mống mắt do đó sẽ tạo ra tổn thương nhiều hơn trên mống mắt, đặt biệt là tạo ra lượng sắc tố mống mắt lớn vào tiền phòng, nguyên nhân gây viêm màng bồ đào và tăng nhãn áp thoáng qua [5], [6]. Hầu hết các trường hợp này có nhãn áp tăng không cao, từ $22-27 \mathrm{mmHg}$, và đáp ứng tốt với thuốc hạ nhãn áp và thuốc chống viêm tra tại chỗ. Do vậy, trong quy trình laser tạo hình mống mắt chu biên trước khi có được hiêu quả ha nhãn áp do mở góc tiền phòng cần dùng thuốc hạ nhãn áp ngay sau laser.

Viêm màng bồ đào (VMBĐ) trước được phát hiện với tỷ lệ cao nhất $8 / 39$ ca $(20,51 \%)$ chiếm $49,98 \%$ tổng số biến chứng sớm. Các ca VMBĐ chủ yếu ở mức độ nhe Tyndall (+) chiếm 75\%, không ca nào có xuất tiết diện đồng tử. Nguyên nhân gây viêm MBĐ trước không do phẫu thuật mà chủ yếu xuất hiện sau laser tạo hình, sắc tố mống mắt và tổn thương mống mắt là nguyên nhân gây viêm. Hầu hết các trường hợp đều ở mức độ nhẹ và được điều trị ổn định bằng chống viêm tra tại chỗ. Sau 2 tuần tỷ lệ này giảm chậm xuống còn $2,56 \%$. Về cơ chế gây VMBĐ có thể thấy rằng nhãn áp tăng cao gây ra tình trạng thiếu máu đột ngột tại bán phần trước, đặc biêt là mống mắt, thể mi dẫn tới tính trạng viêm màng bồ đào ngay cả cắt cơn hoàn toàn do vây trên thực tế chúng tôi đang phẫu thuật trên mắt còn viêm chưa được kiểm soát hoàn toàn. Trong nghiên cứu này, để hạn chế tình trạng viêm này, trước phẫu thuật chúng tôi đã tiến hành điều trị chống viêm tai chỗ và toàn thân cho bênh nhân bằng corticoid, và tương tự sau mổ cũng điều trị hết sức tích cực cả đường tra tại mắt và đường tĩnh mạch. Đánh giá các yếu tố liên quan tới biến chứng VMBĐ này chúng tôi thấy rằng chúng xuất hiện nhiều hơn trên mắt có tăng nhãn áp cao và kéo dài hơn (trên 3 ngày). Hơn nữa, trong phẫu thuật là laser tạo hình đều có tác động vào 
mống mắt do vậy, nguyên nhân gây VMBĐ lại được cộng hợp, tuy nhiên có khoảng thời gian giữa 2 lần phẩu thuật và laser tạo hình nên phần nào hạn chế được các mức đô của viêm, hạn chế ảnh hưởng tới kết quả phẫu thuật cuối cùng.

Ngoài ra, khi đánh giá ảnh hưởng của tai biến, biến chứng lên kết quả phẫu thuật, chúng tôi không thây sự khác biệt giữa nhóm có biến chứng và nhóm không có biến chứng, điều này cho thấy hiệu quả của việc phát hiện và xử lý biến chứng sớm có ý nghî̉a hết sức quan trọng đến kết quả phẫu thuật cuối cùng

\section{KẾT LUẬN}

Phẫu thuật mống mắt chu biên phối hợp laser tạo hình mống mắt chu biên khá an toàn, mặc dù có một tỷ lệ tai biến, biến chứng nhất định nhưng ở mức độ nhẹ, có thể can thiệp dễ dàng không ảnh hưởng đến kết quả cuối cùng.

TÀI LIỆ THAM KHẢO
1. Quigley HA, Broman AT. The number of people with glaucoma worldwide in 2010 and 2020. Br J Ophthalmol; 90:262-7. 2006

2. Nongpiur ME, Ku JY, Aung T. Angle closure glaucoma: a mechanistic review. Curr Opin Ophthalmol; 22:96-101. 2011

3. Edmunds, B., et al. The national survey of trabeculectomy. III. Early and late complications. Eye 16.3: 297-303.2002

4. Playfair, T. JUSTIN, and PETER G. Watson. Management of acute primary angle-closure glaucoma: a long-term follow-up of the results of peripheral iridectomy used as an initial procedure. British Journal of Ophthalmology 63.1,17-22. 1979

5. Ritch R, Tham CC, Lam DS. Argon laser peripheral iridoplasty (ALPI): an update. Surv Ophthalmol. 2007; 52:279-88.

6. Ritch R, Tham CC, Lam DS. Long-term success of argon laser peripheral iridoplasty in the management of plateau iris syndrome. Ophthalmology; 111:104-8.2004

7. Lingam Vijaya, Panday Manish, George Ronnie, and B Shantha. Management of complications in glaucoma surgery. Indian J Ophthalmol, S131-S140.2011

\section{NGHIÊN CỨU TÌNH TRANG DINH DƯỠNG Ở BÊNH NHÂN BÊ̂NH THÂN MẠN GIAI ĐOẠN CUỐI LỌC MÁU CHU KỲ TẠI BỆNH VIỆN HỮU NGHỊ ĐA KHOA NGHỆ AN}

\section{TÓM TẮT}

Muc tiêu: Khảo sát tình trạng dinh dưỡng và các yếu tố liên quan ở bệnh nhân bệnh thận mạn giai đoạn cuối lọc máu chu kỳ. Phưởng pháp nghiên cứu: Nghiên cứu mô tả cắt ngang được thực hiên trên 104 bệnh nhân bệnh thận mạn giai đoạn cuối lọc máu chu kỳ tai khoa Nôi thẩn - Thân nhân tao bênh viên hữu nghị đa khoa Nghệ An. Kết quả: (1)Tỷ lệ bệnh nhân thiếu cân theo BMI là $26,1 \%$; tỷ lê bênh nhân có albumin huyết thanh thấp là $26,9 \%$; đánh giá nguy cơ tổng thể theo chỉ số SGA thì tỷ lệ nguy cơ thiểu dưỡng mức độ $B$ là 40,4\%. (2) 14,4\% bệnh nhân thiếu máu năng; $31,7 \%$ bênh nhân thiếu máu vừa và $47,2 \%$ bệnh nhân thiếu máu nhẹ. (3) Có mối liên quan giữa tình trang suy dinh dưỡng với thời gian loc máu $(p<0,05)$. Kết luận: Tỷ lệ thiếu dưỡng ở bệnh nhân bênh thân man giai đoạn cuối loc máu chu kỳ̀ còn cao, đặc biệt ở nhóm bệnh nhân có thời gian lọc máu lọc máu trên 5 năm. Tư khóa: Suy dinh dưỡng, Bệnh thận mạn giai đoạn cuối

*Đại học Y khoa Vinh

Chịu trách nhiệm chính: Nguyễn Văn Tuấn

Email: tuanminh1975@gmail.com

Ngày nhận bài: 6.5.2021

Ngày phản biên khoa học: 25.6.2021

Ngày duyệt bài: 6.7.2021
Nguyễn Văn Tuấn*

SUMMARY

NUTRITIONAL STATUS IN PATIENTS WITH END-STAGE RENAL DISEASE ON DIALYSIS IN NGHE AN FRIENDSHIP GENERAL HOSPITAL

Objectives: To examine nutritional status and related factors in patients with ESRD on dialysis. Research methodology: A Cross-sectional descriptive study were conducted in 104 the patients with ESRD on dialysis at the Department of Internal Nephrology - Hemodialysis at the Nghe An Friendship General Hospital. Results: (1) The proportion of underweight patients according to BMI is $26,1 \%$; the proportion of patients with low serum albumin is 26,9\%; assessing the overall risk according to the SGA index, the risk of level B of malnutrition is $40,4 \%$. (2) $14,4 \%$ of patients had severe anemia; $31,7 \%$ of patients had moderate anemia and $47,2 \%$ of patients had mild anemia. (3) There is a relationship between malnutrition and dialysis time $(p<0,05)$. Conclusion: The rate of malnutrition in patients with ESRD on dialysis is still high, especially in patients with dialysis time more than 5 years.

Key words: Malnutrition, ESRD

\section{I. ĐẶT VẤN ĐỀ}

Bệnh thận mạn đang trở thành bệnh lý phổ biến hiện nay với tỷ lệ mắc bệnh ngày càng gia 